SŁAWOMIR DRELICH

ORCID 0000-0003-0620-893X

Uniwersytet Mikołaja Kopernika

$w$ Toruniu

\title{
KRYTYKA WSPÓŁCZESNEGO UNIWERSYTETU WEDŁUG AYN RAND I ALLANA BLOOMA
}

\begin{abstract}
AвStract. Drelich Sławomir, Krytyka wspótczesnego uniwersytetu wedtug Ayn Rand i Allana Blooma [Ayn Rand and Allan Bloom's Critique of Contemporary Universities]. Studia Edukacyjne nr 57, 2020, Poznań 2020, pp. 209-225. Adam Mickiewicz University Press. ISSN 1233-6688. DOI: 10.14746/ se.2020.57.15

Ayn Rand and Allan Bloom are among the most well-known American critics of the contemporary universities. They both point out that the crisis of modern university is a reflection of a much broader crisis of contemporary culture. The purpose of this text is to present the arguments of both thinkers, which confirm the diagnosis of the university crisis. In Rand and Bloom's work we can find the characteristics of a number of symptoms of this crisis. The most important are: 1) the political and ideological entanglement of the university environment; 2) all-encompassing skepticism; 3) the lack of a coherent vision of reality; 4) irrationality and departure from reason; 5) the postulate of neutrality and the avoidance of moral judgments; 6) retreat from philosophy and humanistic education.
\end{abstract}

Key words: university, crisis of culture, irrationality, skepticism

\section{Wprowadzenie \\ Sentyment Rand i Blooma do uniwersyteckiej wspólnoty}

Ayn Rand i Allan Bloom to najbardziej znani amerykańscy krytycy stanu uniwersytetów i edukacji w Stanach Zjednoczonych. Choć często również krytyczni wobec siebie, raczej nieznani ze współpracy czy podejmowania tych samych inicjatyw, w wielu zagadnieniach dotyczących jakości kształcenia na amerykańskich uczelniach wyższych zgadzali się, nierzadko prezentując analogiczne wnioski bądź prognozy. Rand była imigrantką z Rosji, która przybyła do Stanów Zjednoczonych kilka lat po rewolucji październikowej, 
pochodziła z zamożnej rodziny żydowskich aptekarzy; Bloom pochodził z biednej, robotniczej rodziny z Indianapolis, osiadłej później w Chicago, który dzięki programom stypendialnym ukończył studia. Rand po przyjeździe do Ameryki pracowała w show-biznesie: pisała sztuki teatralne i scenariusze filmowe, później poświęciła się powieściopisarstwu i publicystyce wolnościowej; Bloom zrobił karierę uniwersytecką, studiował w Niemczech i Francji, był związany z uniwersytetami: Yale, Cornell, University of Toronto i University of Chicago. Rand zdobyła sławę jako autorka bestsellerowych powieści Atlas zbuntowany ${ }^{1}$ i Źródło2, opowiadania $H_{y m n}{ }^{3}$ oraz esejów i felietonów wydanych w zbiorach: Cnota egoizmu, Nowa koncepcja egoizmu ${ }^{4}$ oraz Powrót człowieka pierwotnego. Rewolucja antyprzemystowa ; do najważniejszych dzieł Blooma zalicza się natomiast takie pozycje, jak: Umyst zamknięty ${ }^{6}$, Szekspir i polity $k a^{7}$ oraz The Republic of Plato ${ }^{8}$. Rand była publicystką promującą idee wolnościowe i kapitalistyczne oraz antropologiczny indywidualizm, krytykującą rozbudowane struktury państwowe i społeczny konformizm; Bloom usiłował odbudować rolę filozofii we współczesnym społeczeństwie, rozważał miejsce filozofa w życiu publicznym, interesowały go również miłość i przyjaźń, które były tematami jego popularnych prac. Oboje obrali różne drogi życiowe, mieli zdecydowanie odmienne temperamenty, jednak spostrzeżenia Rand i Blooma dotyczące współczesnej edukacji wyższej, jak również wypływające z nich wnioski a propos stanu kultury i cywilizacji Zachodu oraz natury ludzkiej sprawiają, że stają się sobie bardzo bliscy. Celem niniejszego artykułu jest zaprezentowanie owej bliskości intelektualnej Rand i Blooma w dziedzinie ich ocen dotyczących amerykańskiego szkolnictwa wyższego. Kanwą do tekstu stały się dwa fundamentalne dzieła poruszające te zagadnienia, a mianowicie zbiór esejów Rand zatytułowany Powrót człowieka pierwotnego oraz studium Blooma noszące tytuł Umyst zamknięty, jednakże powstanie tekstu nie byłoby możliwe bez szeregu innych prac obojga autorów, w których podjęli się analizy tychże zagadnień.

To, co łączy Rand i Blooma, to sentyment do uniwersyteckiej wspólnoty w rozumieniu klasycznym oraz przekonanie, że edukacja uniwersytecka stanowi szczególną formę realizacji ludzkiego pędu do wiedzy i mądrości. Ranga edukacji wskazywana jest przez Blooma w jego inspirującej interpre-

\footnotetext{
${ }^{1}$ A. Rand, Atlas zbuntowany, przekł. I. Michałowska, Poznań 2008.

2 A. Rand, Źródło, przekł. I. Michałowska, Poznań 2007.

3 A. Rand, Hymn, przekł. S. Bijak, Poznań 2001.

${ }^{4}$ A. Rand, Cnota egoizmu. Nowa koncepcja egoizmu, przekł. J. Łoziński i in., Poznań 2000.

${ }_{5}$ A. Rand, Powrót człowieka pierwotnego. Rewolucja antyprzemysłowa, przekł. Z.M. Czarnec-

${ }^{6}$ A. Bloom, Umyst zamknięty, przekł. T. Bieroń, Poznań 2012.

7 A. Bloom, Szekspir i polityka, Kraków 1995.

8 A. Bloom, The Republic of Plato, Basic Books 1968.
} ki, Poznań 2003. 
tacji Państwa Platona, w której podkreśla on, że „istnieje doskonała harmonia między filozofią a polis oraz między nauką a społeczeństwem” ${ }^{9}$. Oznacza to - jego zdaniem - że „w edukacji liczy się tylko natura, że ludzkie pragnienie wiedzy jest niezmienne, że należy je tylko odpowiednio pobudzać, że edukacja polega tylko na postawieniu pożywienia na stole"10. Rand wiąże edukację i rozwój z powstaniem filozofii. Dostrzega, że „człowiek stanął na własnych nogach dopiero w starożytnej Grecji, około dwa i pół tysiąca lat temu. Narodziny filozofii oznaczały początek jego dorosłości"11. Oboje dostrzegają więc ogromną rolę kształcenia, jednakże przemawia przez nich tęsknota do klasycznych kanonów, humanistycznych podstaw i antycznych źródeł uniwersytetu. Oboje stawiają także pytanie, które do dziś wraca w opracowaniach i analizach, a mianowicie:

czy edukacja winna być miejscem kształcącym w technice życia, mającym dostarczać konkretnych umiejętności praktycznych pomocnych $\mathrm{w}$ znalezieniu dobrej pracy? Czy może kontemplacyjnym przyswajaniem sobie mądrości i czasem nieustających poszukiwań? ${ }^{12}$

Rand dostrzegała - podobnie jak Bloom - że współczesna degradacja uniwersytetu, a w szczególności

zniszczenia dokonywane $\mathrm{w}$ humanistyce, w filozofii, stają się powoli, acz systematycznie, zbyt wielkie. Na skutek których idea uniwersytetu stanie się w niedługim czasie zupełnie niezrozumiała. I niemożliwa do zrozumienia ${ }^{13}$.

Stąd właśnie strach Rand i Blooma o uniwersytet jako nośnik nie tylko wykształcenia, ale przede wszystkim kultury, wartości i ethosu. Z niniejszych rozważań dotyczących krytyki współczesnych szkół wyższych wyłoni się również a contrario wyobrażenie obojga myślicieli na temat właściwie - w ich opinii - rozumianego i zorganizowanego uniwersytetu.

\section{Defekt 1: Polityczne uwikłanie zamiast niezależnych poszukiwań}

W Atlasie zbuntowanym Rand docenia rolę dawnych nauczycieli, którzy nie ulegali współczesnym modom i modelom kształcenia, a „wychowali ludzi, którzy stworzyli ten kraj"14. Rola nauczyciela jako swego rodzaju przewodnika i mentora, a tym samym szczególna relacja między wykładowcą a studentem, stanowiły fundament akademii. Dlatego właśnie Bloom na-

\footnotetext{
${ }^{9}$ A. Bloom, Interpretive Essay, [w:] Tamże, s. 309 [przekł. własny].

10 A. Bloom, Umyst zamknięty, s. 60.

11 A. Rand, Powrót człowieka pierwotnego, s. 68.

12 M.J. Czarnecki, Co znaczy Uniwersytet? Dialogi Polityczne, 2007, 7, s. 12.

${ }_{13}$ M. Polakowski, O zmierzchu pewnej idei, Dialogi Polityczne, 2007, 7, s. 52.

${ }^{14}$ A. Rand, Atlas zbuntowany, s. 1002.
} 
uczanie przyrównuje do położnictwa ${ }^{15}$, czyli sztuki wydobywania z ucznia wiedzy, umiejętnego pozwalania mu, aby sam dokonywał odkryć. Taki „nauczyciel woli obiecujące «być może» od niedoskonałego «jest»"16. Większość współczesnych amerykańskich wykładowców uniwersyteckich - jak przekonują Rand i Bloom - nie spełnia tych kryteriów, a tym samym ich uczniowie i studenci z dużo mniejszym prawdopodobieństwem uzyskają osiągnięcia porównywalne z osiągnięciami ich rodziców czy dziadków. Swoiste kierownictwo intelektualne nauczyciela nad uczniem czy studentem musi być zatem wolne od doktrynerstwa, ideologii i politycznych uwikłań. Paradoksem jest, iż statystyki dotyczące części populacji, która uzyskała wyższe wykształcenie, powinny napawać dumą bądź przynajmniej zadowoleniem. Jednakże, zdaniem Blooma,

wrażenie, że ludność Ameryki jest teraz lepiej wykształcona opiera się na dwuznaczności słowa wykształcenie, czy też na zatarciu rozróżnienia pomiędzy studiami technicznymi i liberalnymi. Wybitny fachowiec od komputerów niekoniecznie posiada większą wiedzę w dziedzinie moralności, polityki i religii niż osoby o znikomym wykształceniu $^{17}$.

Autorka Powrotu człowieka pierwotnego - po obserwacji wydarzeń studenckiej rewolty w University of California w Berkeley, która rozpoczęła się jesienią 1964 roku - konkluduje, że amerykańskie szkoły wyższe od końcówki lat 60 . stały się polem ideologicznej walki, w której w sposób bezdyskusyjny zwycięstwo odniosły środowiska nowej lewicy. To im - zdaniem Rand - udało się uzyskać kontrolę nad programami kształcenia, polityką kadrową oraz rekrutacyjną, tworzenie nowej, zdemokratyzowanej struktury i organizacji uczelni. Co jednak istotne, pod wpływem tychże lewicowych ideologii - jej zdaniem - znalazła się większość wykładowców, którzy stali się istotnym elementem o realnym wpływie na przebudowę uniwersytetu ${ }^{18}$.

Rand przypomina, że w trakcie wydarzeń strajków studenckich w Berkeley, ale również w innych amerykańskich szkołach wyższych, nieustannie pojawiał się postulat demokratyzacji zarządzania uniwersytetami oraz konieczności przekazania odpowiedzialności za zarządzanie nimi także tym, którzy dotychczas takiego wpływu byli pozbawieni, między innymi studentom. Autorka Atlasa zbuntowanego twierdzi, że „bezpośrednim celem jest najwyraźniej przejęcie uniwersytetów" ${ }^{\prime \prime}$. Po wydarzeniach rebelii lat 60 . dochodzi Rand do wniosku, że „ich plan minimum to po prostu stwarza-

\footnotetext{
${ }^{15}$ A. Bloom, Umyst zamknięty, s. 22.

16 Tamże, s. 23.

17 Tamże, s. 71.

18 A. Rand, Powrót człowieka pierwotnego, s. 16-28.

19 Tamże, s. 25.
} 
nie kłopotów - utrudnianie, zakłócanie, demoralizowanie i niszczenie. Ich plan ostateczny to przejęcie władzy” ${ }^{20}$. W efekcie zaś „rządy grup nacisku stanowią jedynie preludium, społeczne przygotowanie do rządów gangu"21. Również Bloom zwraca uwagę, iż w latach 60. uniwersytety amerykańskie - na wzór niemieckich i francuskich - stały się areną rozprzestrzeniania się wpływów lewicowych ideologów. Początkowo wśród studentów zaczęły powstawać organizacje włączające się w ruch praw obywatelskich i walkę z rasizmem oraz dyskryminacją kolorowych Amerykanów, później wpływy zaczęły budować środowiska feministyczne. Działania ich zmierzały do walki z trzema - jak przywołuje Bloom - kardynalnymi grzechami wrogów egalitaryzmu: rasizmem, seksizmem i elityzmem²2. Sami zaś buntujący się studenci jako naczelne narzędzie walki z krytykowanym systemem przyjmowali przemoc i agresję. Co jednak ciekawe, Rand przywołuje, w jaki sposób buntownicy z Berkeley usiłowali tworzyć pseudoteoretyczne rozróżnienie na siłę i przemoc, wskazując jednocześnie, że siła nie jest przemocą i dlatego należy ją traktować jako normalną metodę walki ${ }^{23}$. Tym samym, doprowadzono do odwrócenia „moralnego wartościowania - moralne staje się zapoczątkowanie użycia siły, a niemoralne: przeciwstawienie się jej"24. Bloom ubolewa nad biernością wykładowców wobec uczynienia z uniwersytetów pola politycznej walki:

Profesorowie, depozytariusze naszych najlepszych tradycji i najwyższych aspiracji intelektualnych, płaszczyli się przed zwykłą hołotą; publicznie wyznali winę i przeprosili za to, że do tej pory nie rozumieli najważniejszych kwestii moralnych: właściwej postawy w tych kwestiach nauczył ich motłoch; wyrazili wolę zmiany celów uniwersytetu i nauczanych przez siebie treści ${ }^{25}$.

Rand przypomina, że zachowanie protestujących dowiodło, iż „niektórzy studenci uważali, że mają prawo złamać przepisy, by wymusić zmianę. Ale czyniąc tak, osiągnęli szczyt idealistycznej hipokryzji" ${ }^{26}$. Po zajściach wymuszono na uniwersytetach zastosowanie zasady ne bis in idem - jeśli więc student został uprzednio ukarany prawnie za swoje zachowanie w trakcie protestów, wówczas uczelnia nie może zastosować wobec niego żadnych sankcji wewnętrznych. Jednocześnie domagano się, aby uniemożliwić obcią-

\footnotetext{
20 Tamże, s. 39.

21 Tamże, s. 40.

22 A. Bloom, The Crisis of American Democracy and Liberal Education. Collected Essays, Internet Archive 1986, s. 157-159.

23 A. Rand, Powrót człowieka pierwotnego, s. 44.

24 Tamże, s. 45.

25 A. Bloom, Umyst zamknięty, s. 409.

26 A. Rand, Powrót człowieka pierwotnego, s. 27.
} 
żanie protestujących cywilnymi konsekwencjami ich czynów ${ }^{27}$. Organizatorzy studenckich wystąpień głosili, że „wolność wypowiedzi oznacza wolność działania" ${ }^{28}$, przyznając sobie tym samym prawo do podejmowania tak radykalnych działań.

\section{Defekt 2: Pułapka sceptycyzmu zamiast poszukiwania pewności}

Uniwersytet $\mathrm{w}$ jego wersji tradycyjnej miał być instytucją, która uczy młodego człowieka poszukiwania prawdy, jednocześnie zbliżając go do niej. Uniwersytet był zatem postrzegany jako nie tylko instytucja edukacyjna, ale również wspólnota przysposabiająca studenta do rozumienia współczesnego świata. Uniwersytet miał ponadto tego nieokrzesanego młodego człowieka, którym niejednokrotnie targają popędy i pożądliwości, wychować na istotę moralną. Tymczasem - jak wskazują Rand i Bloom - uniwersytet współczesny ani nie skupia się na poprowadzeniu młodych ludzi do prawdy, ani nie bierze na siebie roli wspólnoty, ani nie pragnie wychowywać. Oboje przekonują, że spowodowane to jest przyjęciem przez współczesne uniwersytety paradygmatu radykalnego sceptycyzmu. Rand już w Cnocie egoizmu dostrzega, że

gdyby jednak wątpienie i niepewność miały charakteryzować właściwy stan moralny człowieka, gdyby świadectwem cnoty miała być niewiara w siebie i w możność polegania na sobie, (...) to moralnym ideałem byłaby choroba umysłowa, a najwspanialszymi uosobieniami moralności staliby się neurotycy i psychotycy, myśliciele zaś i zdobywcy okazali się grzesznikami ${ }^{29}$.

Skutkami takiego radykalnego sceptycyzmu są - jak wskazuje Rand epistemologiczny agnostycyzm, zdeklarowany irracjonalizm oraz etyczny subiektywizm, czyli największe bolączki współczesnych sal wykładowych. Wskazuje ona ponadto, że „nasze czasy są świadkami ostatecznego przesilenia - zbierania pokłosia długiego procesu destrukcji - dokonującego się na końcu drogi wytyczonej przez Kanta" ${ }^{30}$. Prawda została de facto wyeliminowana z uniwersytetu, który przecież został powołany do jej poszukiwania. Według Blooma, skutkuje to tym, że „należy w ogóle wyrzec się przekonania, że ktokolwiek może mieć rację"31. Zgodziłby się tutaj na pewno z autorką Powrotu człowieka pierwotnego, która w swoim eseju poświęconym studenckim rebeliom lat 60. konkluduje, iż nagle każdy przejaw „intelektualnej pewności” zaczął być traktowany jako „wyraz mentalności dyktatorskiej” ${ }^{32}$. Bloom

\footnotetext{
27 Tamże, s. 49.

28 Tamże, s. 45.

29 A. Rand, Cnota egoizmu, s. 45-46.

30 A. Rand, Powrót człowieka pierwotnego, s. 29.

31 A. Bloom, Umyst zamknięty, s. 29.

32 A. Rand, Powrót człowieka pierwotnego, s. 30.
} 
dostrzega, że ów sceptycyzm stał się chorobą całego środowiska uniwersyteckiego i „radykalnie zmienił się sens bycia profesorem”, a to dlatego że „wielu profesorów zaczęło wątpić w wartość tego, czego nauczali" ${ }^{33}$. Skoro więc $\mathrm{w}$ ową pułapkę sceptycyzmu wpadła uniwersytecka profesura, toteż nie może dziwić fakt, iż w takim duchu kształtowani są młodzi ludzie.

Rand pesymistycznie podsumowuje, że rezultatem ukończenia przez młodego człowieka edukacji we współczesnym uniwersytecie jest wypełnienie

następującym osadem w mózgu: egzystencja jest nieopisaną, niepoznawalną dżunglą, lęk i niepewność są trwałym stanem człowieka, cynizm stanowi oznakę realizmu, a nade wszystko - znamieniem intelektualisty jest zaprzeczanie istnieniu intelektu ${ }^{34}$.

Oprócz tego wszystkiego, współczesny uniwersytet nie wyposaża człowieka $\mathrm{w}$ odpowiedni bagaż wiedzy i intelektualnych podstaw kultury, w której przyszło mu żyć. Bloom z doświadczeń własnej pracy akademickiej wysuwa wniosek, iż „studenci, którzy przychodzą dziś na uniwersytet, nie mogą się krytycznie ustosunkować do naszej tradycji politycznej, gdyż słabo ją znają, nie mogą też się nią inspirować, gdyż myślą o niej z cynizmem"35. W eseju Upadek Uniwersytetu Bloom pisze, że

tradycja uległa degeneracji; opinia publiczna została zniewolona; zanikły idee; literatura coraz trudniej znajduje oddźwięk w życiu naszym i wyrobionego czytelnika; autorzy ulegają rynkowi; wzrosło nasze upodobanie do komunałów, ponieważ doświadczenie i studia nie wykształcają już bogatej, konkretnej świadomości; nauki społeczne skłaniają się coraz bardziej do deterministycznego ujęcia natury człowieka, gdyż coraz mniej wierzymy w wolność jednostki w masowym społeczeństwie egalitarnym ${ }^{36}$.

Okazuje się, że efektem takiego oddziaływania są ukształtowane „młode istoty pełne chronicznego przerażenia, krzyczące, że nic nie wiedzą i chcące rządzić wszystkim" ${ }^{37}$. Ani bowiem współczesny uniwersytet, ani cały system edukacji nie zapewniają młodemu człowiekowi właściwej pomocy w wypływających z natury ludzkiej poszukiwań prawdy i pewności. Współczesna edukacja ponadto „nie wymaga przyjęcia żadnego niekwestionowalnego zespołu przekonań"38. Rand dostrzega, że „niepewność i sceptycyzm są cechami wartościowymi społecznie, sprzyjającymi tolerancji dla różnic, elastyczności, socjalnemu «dopasowaniu» i gotowości do kompromisu"39. Tak skonstru-

\footnotetext{
33 A. Bloom, Upadek Uniwersytetu, przekł. A. Serafin, Kronos, 2016, 4, s. 245.

34 A. Rand, Powrót człowieka pierwotnego, s. 30.

35 A. Bloom, Umyst zamknięty, s. 67.

36 A. Bloom, Upadek Uniwersytetu, s. 245.

37 A. Rand, Powrót człowieka pierwotnego, s. 29.

38 A. Bloom, Umyst zamknięty, s. 31.

39 A. Rand, Powrót człowieka pierwotnego, s. 30.
} 
owany system intelektualnego kształtowania jednostki jest więc jedynie dopasowaniem do realiów demokratycznego, egalitarnego i pluralistycznego społeczeństwa. Apologeci opartej na powszechnym sceptycyzmie organizacji systemu kształcenia przekonują, że

pełną wolność można osiągnąć jedynie wtedy, gdy nie istnieją żadne moralne i polityczne pewniki. Skutecznym sposobem unieszkodliwienia prześladowców jest przekonać ich, że nie wiedzą, czym jest dobro ${ }^{40}$.

Sceptycyzm stanowi więc formę walki z wszystkimi, którzy jakieś zasady przyjmują i wierzą w określony katalog wartości. Bloom przestrzega przed zgubnymi skutkami takiego kształcenia i zachęca, aby przyjrzeć się praktyce uniwersyteckiej, wsłuchać się,

jak profesorowie uczą wasze dzieci, że człowiek nie może być niczego pewien, że jego świadomość nie jest nic warta, że nie może poznać faktów ani praw istnienia, że jest niezdolny do poznania obiektywnej rzeczywistości ${ }^{41}$.

Taki manifest programowo-metodyczny współczesnego uniwersytetu może stać się - zdaniem Rand i Blooma - przyczyną zahamowania postępu intelektualnego i naukowego, ale również poskutkuje nieznajomością przez człowieka swoich korzeni i pochodzenia oraz zatraceniem poczucia ciągłości.

\section{Defekt 3: Rozczłonkowana rzeczywistość zamiast spójnej wizji świata}

Zdaniem Blooma uniwersytet upadł, natomiast obecnie jego miejsce zajmuje "multiwersytet” - „pluralistyczny model uniwersytetu pozbawionego naczelnej zasady organizacyjnej" ${ }^{\prime 2}$. Ten nowy model uczelni wyższej - multiwersytet - stał się „częścią systemu idei i celów otaczającego go społeczeństwa”, realizującym „utylitarne, wyznaczone przez społeczeństwo cele" ${ }^{\prime 3}$. Współczesny uniwersytet uległ dramatycznemu rozczłonkowaniu: wydziały wchodzące formalnie w jego skład uzyskały niespotykaną dotychczas autonomię, nie funkcjonują już na podstawie solidarnej realizacji jakiegoś jednego określonego celu, często znajdują się wręcz w konflikcie. Zniknęło jednocześnie dotychczasowe przeświadczenie, że wszystkie części są jedynie elementami większej całości ${ }^{44}$. Takie organizacyjno-strukturalne rozczłonkowanie uczelni wyższej sankcjonuje niejako rzeczywiste funkcjonowanie każdego z członów jako odrębnego podmiotu, kierującego się własnymi dążeniami

${ }^{40}$ A. Bloom, Umyst zamknięty, s. 32.

${ }^{41}$ A. Rand, Atlas zbuntowany, s. 698.

${ }^{42}$ A. Bloom, Upadek Uniwersytetu, s. 241. Informacja tłumacza w przypisie 1 tekstu.

43 Tamże.

${ }^{44}$ I. Chłodna-Błach, The Crisis of American Education and Reforms Proposals according to Allan Bloom, Studia Gilsoniana, 2004, 3, s. 261. 
i interesami, na własny sposób definiującego proces kształcenia studenta oraz programy nauczania na poszczególnych kierunkach czy też wykładanych przedmiotach. Jednakże, towarzyszy temu również swego rodzaju rozczłonkowanie merytoryczne. Jak bowiem wskazuje Rand, „treści nauczane w tym samym czasie w ramach różnych przedmiotów nie są w żaden sposób wzajemnie powiązane, a często sobie przeczą" ${ }^{45}$. Można więc mówić nie tylko o daleko posuniętej autonomii poszczególnych wydziałów, ale również niezależności kierunków kształcenia, a także wykładowców w ramach poszczególnych przedmiotów. I bynajmniej nie chodzi Rand o krytykę autonomii jako takiej - jako zwolenniczka idei wolności byłaby od tego daleka - ale o autonomiczność, z którą w parze idzie wyraźna separacja poszczególnych członów uniwersyteckiej rzeczywistości. Samodzielność pracy badawczej - w jej opinii - nie musi iść w parze z brakiem jakiejkolwiek wspólnej wizji kształcenia, jaka powinna być celem społeczności akademickiej solidarnie realizowanym, a działania poszczególnych członów akademii winny być względem siebie komplementarne.

Rand i Bloom zgodnie twierdzą, że takie rozczłonkowanie uniwersytetu jest odbiciem analogicznego rozczłonkowania egalitarnego społeczeństwa demokratycznego, które trudno interpretować z perspektywy wielkiej państwowej wspólnoty, w większym zaś stopniu przypomina sumę pomniejszych wspólnot i stowarzyszeń opartych na partykularnych interesach. Demokracja pragnie również ukształtować człowieka takim, jaki w egalitarnej i rozczłonkowanej rzeczywistości społecznej funkcjonowałby sprawnie, a zarazem okazałby się na tyle niekłopotliwy, aby uniemożliwiać dysharmonizację działania demokratycznego państwa. Zatem - jak twierdzi Bloom - charakterystyczny dla demokracji i egalitaryzmu

system edukacyjny, czy się do tego przyznaje, czy nie, chce i potrzebuje stworzyć ludzi obdarzonych takimi upodobaniami, wiedzą i charakterem, które sprzyjają ustrojowi demokratycznemu ${ }^{46}$.

Takimi przymiotami są niewątpliwie tolerancja i zarazem niechęć do wszelkich absolutyzmów, wspomniany już sceptycyzm oraz nieufność względem wszelkich potencjalnych autorytetów. Rand wskazuje, że wspólcześni kolektywiści - tak określa zwolenników między innymi różnorodnych ruchów lewicowych - rezygnują z uznawania jakichkolwiek autorytetów indywidualnych, natomiast cechy autorytetu przyznają zbiorowościom, względem których jednostka powinna wykazać pokorę i uległość ${ }^{47}$. Bloom

\footnotetext{
45 A. Rand, Powrót człowieka pierwotnego, s. 98.

46 A. Bloom, Upadek Uniwersytetu, s. 30.

47 A. Rand, Cnota egoizmu, s. 157.
} 
dostrzega, że paradoksalnie w egalitarnym społeczeństwie nawet „rodzice nie posiadają autorytetu prawnego i moralnego, którym cieszyli się w Starym Świecie"48, jednocześnie "nauka moralna w rodzinie sprowadza się obecnie do wpojenia absolutnego minimum reguł zachowań społecznych"49. Rand stwierdza, że rezygnacja - tak w rodzinie, jak też w ramach systemu edukacyjnego - z kształcenia w duchu wartości skutkuje de facto zezwierzęceniem człowieka ${ }^{50}$. Autorytet $w$ egalitarnych społeczeństwach niejednokrotnie jest utożsamiany - szczególnie zaś przez młodych ludzi - z absolutyzmem, natomiast "tym, czego nauczono ich się obawiać $w$ absolutyzmie, jest nie pomyłka w ocenie, lecz nietolerancja" ${ }^{51}$. Bloom oczekuje, aby każdy nauczyciel miał świadomość, że „niemal każdy student przychodzący na uniwersytet sądzi, a przynajmniej tak mu się wydaje, że prawda jest względna"52. Młodzi ludzie tak ukształtowani - z rozczłonkowaną wizją świata - wymagają wyjątkowego podejścia. Należy bowiem

uświadomić im, że ich preferencje są jedynie przypadkowym wytworem miejsca i cza$\mathrm{su}^{53}$ oraz że z wielką subtelnością i energią telewizja wkracza nie tylko do pokoju, ale także w gusta starych i młodych, odwołując się do tego, co sprawia natychmiastową przyjemność, a podkopując wszystko, co w jej doznawaniu przeszkadza ${ }^{54}$.

Celem zasadniczym powinno być więc przynajmniej podjęcie próby przezwyciężenia tego intelektualnego rozczłonkowania, skłonienie młodych lu-

${ }^{48}$ A. Bloom, Umyst zamknięty, s. 70. Nathaniel Branden, jeden z najbliższych współpracowników Rand, w jednym ze swoich esejów wskazuje przykład współczesnych rodziców, którzy starają się wychowywać swoje dziecko w duchu relatywizmu, sceptycyzmu i nihilizmu: „Co powiedzieć o dziecku, które przerażone cofa się w autystyczne odludzie, gdyż nie może sobie poradzić z naukami rodziców, którzy powiadają mu, że z natury jest winne, że ciało jest źródłem zła, myślenie jest grzechem, stawianie pytań bluźnierstwem, wątpienie przejawem deprawacji, ono zaś musi wykonywać nakazy nadzmysłowego ducha, inaczej bowiem na wieki wieków będzie płonęło w piekle?" N. Branden, Zdrowie umystowe versus mistycyzm i samopoświęcenie, [w:] A. Rand, Cnota egoizmu, s. 48.

49 A. Bloom, Umyst zamknięty, s. 73.

${ }^{50}$ W eseju Etyka absolutna Rand podkreśla, że zwierzęta kierują się automatyzmami, zaś człowiek zawsze musi dokonać racjonalnego wyboru hierarchii wartości, które staną się dla niego celami ultymatywnymi i zdefiniują jego drogę życiową: „Człowiek nie posiada automatycznego systemu przetrwania. Nie ma automatycznie wyznaczonego kierunku postępowania ani automatycznego zbioru wartości. Jego zmysły nie podpowiadają mu automatycznie, co jest dla niego dobre, a co złe, co przyniesie korzyść jego życiu, a co mu zagrozi, jakie cele powinien realizować i za pomocą jakich środków, od jakich wartości zależy jego życie i jakiego postępowania one wymagają". A. Rand, Cnota egoizmu, s. 19.

${ }^{51}$ A. Bloom, Umyst zamknięty, s. 29.

52 Tamże, s. 28.

53 Tamże, s. 34.

${ }^{54}$ Tamże, s. 70. 
dzi do bardziej krytycznego podejścia wobec systemu, w którym przyszło im się kształcić i wychowywać.

\section{Defekt 4: Religia irracjonalności zamiast przewodnictwa rozumu}

Rand twierdzi, że „od czasu gdy Kant oddzielił rozum od rzeczywistości, jego intelektualni następcy pilnie poszerzali tę przepaść" ${ }^{55}$. Wrogość do rozumu jest - według niej - szczególnym znakiem wielu dwudziestowiecznych ruchów społecznych, które jednakowoż wielokrotnie przedstawiają się jako deklaratywnie racjonalistyczne. Tymczasem jednak lewicowi bojownicy rebelii lat 60. „ogłosili moralną wyższość «instynktów», popędów i uczuć oraz poznawczą moc żołądków, mięśni, nerek, serc i krwi. Była to rewolta bezgłowych ciał" 56 . Rand podkreśla, że fakt odrzucenia rozumu przez autorów i uczestników studenckiej rebelii doprowadził w istocie do rozlania się przemocy ${ }^{57}$. Zarówno Rand, jak też Bloom, broniąc rozumu i ludzkiej racjonalności, powołują się na racjonalistyczne źródła filozofii klasycznej. Bloom podkreśla, że właśnie u starożytnych mamy do czynienia z prymatem rozumu i cnoty nad uczuciami ${ }^{58}$. Dwudziestowieczna lewica domaga się - wedle Rand - zerwania z tym prymatem i dowartościowania uczuć. Dostrzega ona, że porzucenie rozumu w sposób szczególny uderza w uniwersytet jako instytucję i wspólnotę, w której rozum jako narzędzie zyskał szczególną rangę, stając się jednocześnie instrumentem umożliwiającym poznanie. Autorka Powrotu człowieka pierwotnego przestrzega przed „,antyracjonalną indoktrynacją”, która - jej zdaniem - „odbywa się w formie jednostronnie zniekształconego doboru tematów, mistyczno-altruistyczno-kolektywistycznych sloganów i propagowania wyższości emocji nad rozumem" ${ }^{59}$. Bloom ukazuje odejście od rozumu jako proces szerszy, obejmujący nie tylko uniwersytety amerykańskie, ale całe społeczeństwa egalitarnej demokracji. Rozumie, że

dla narodów współczesnych, które w większym stopniu niż dawne opierają się na rozumie, kryzys uniwersytetu, siedliska rozumu, jest bodaj najpoważniejszym kryzysem, któremu muszą stawić czoło ${ }^{60}$.

Rand stawia sprawę bardzo mocno: domaga się, aby każdy student, który deklaruje odrzucenie rozumu, został wydalony z uniwersytetu jako osoba, która podważa w ogóle uniwersytecki ethos, zapominając lub nie będąc świadomym, iż „rozum i moralność to jedyne rodzaje broni, od których zależy

\footnotetext{
55 A. Rand, Powrót człowieka pierwotnego, s. 29.

56 Tamże, s. 31.

57 Tamże, s. 38.

58 Zob. A. Bloom, Romeo i Julia, Kronos, 2011, 3, s. 46.

59 Tamże, s. 99.

${ }^{60}$ A. Bloom, Umyst zamknięty, s. 26.
} 
bieg historii” i dlatego „nie można się spierać z ludźmi, którzy sami przyznają, że są irracjonalistami” ${ }^{\prime \prime 1}$. Każda dyskusja - również każdy spór - wymagają przecież posługiwania się rozumem i odwołania się do jego potęgi. To sprawia, że Rand nie widzi pola do konsensusu między obrońcami a wrogami rozumu i racjonalności. Nie ma bowiem żadnego sposobu na znalezienie "złotego środka" między człowiekiem racjonalnym a człowiekiem pierwotnym - odwrót bowiem od rozumu nie jest niczym innym, jak „powrotem człowieka pierwotnego".

\section{Defekt 5: Iluzja neutralności zamiast rzetelnej oceny moralnej}

Rand i Bloom zgodnie wskazują, że rewolta studencka na amerykańskich uniwersytetach powiodła się i udało się wprowadzić wiele oczekiwanych przez środowiska nowej lewicy zmian zarówno merytoryczno-programowych, jak też organizacyjno-strukturalnych. W pewnym stopniu przyzwolenie na tak radykalne zmiany wyniknęło z - jak twierdzi Rand - tchórzostwa administratorów szkół wyższych i przyjętej przez nich polityki moralnej neutralności ${ }^{62}$. Zarządzający uniwersytetami, a także większość kadry profesorskiej zdecydowała się na przyjęcie postawy neutralnej i niewłączanie się w dyskusję na temat przewidywanych zmian, kiedy były one już przesądzone. Takim milczącym niejako sposobem pozwolono, aby uniwersytety zostały zdominowane przez kulturowy relatywizm i dogmatyczny sceptycyzm ${ }^{63}$. Bloom zgadza się $w$ tych ocenach $z$ Rand, podkreślając, że niewątpliwie tym, co łączy wszystkich współczesnych studentów niezależnie od ich pochodzenia jest relatywizm i dążenie do zaprowadzenia powszechnej równości ${ }^{64}$. Postulat neutralności wymusza, aby w ramach uniwersytetu nie dokonywano żadnych rozróżnień między studentami, aby również nie podlegały ocenie ich postawy moralne. Uniwersytet miał stać się miejscem sterylnym pod względem aksjologicznym, jednakże paradoksalnie okazało się, że sama "odmowa czynienia rozróżnień" stała się nowym nakazem moralnym, zaś jej przeciwieństwem - dyskryminacja. Bloom dobitnie podkreśla, że „ten obłąkańczy pogląd oznacza, że człowiekowi nie wolno odnajdywać w innych dobra i go chwalić, gdyż odkrycie dobra to jednocześnie odkrycie zła i pogarda dla niego" ${ }^{\prime 65}$. Rand i Bloom domagają się w murach uniwersytetu nie tylko rzetelności naukowej, ale również uczciwości intelektualnej i prostolinijności moralnej.

\footnotetext{
${ }^{61}$ A. Rand, Powrót człowieka pierwotnego, s. 60.

${ }^{62}$ Tamże, s. 36.

${ }^{63}$ I. Chłodna-Błach, The Crisis of American Education, s. 263.

${ }^{64}$ A. Bloom, Umyst zamknięty, s. 28.

${ }^{65}$ Tamże, s. 35.
} 
Tak zadeklarowana neutralność moralna sprawia, że uniwersytet traci możliwość zdefiniowania i propagowania pozytywnych wzorców moralnych, które dotychczas stanowiły niezwykle istotne narzędzie kształtowania postaw moralnych $\mathrm{w}$ młodych ludziach. Bloom interpretuje taką wrogość wobec transparentnego wskazywania postaw perfekcjonistycznych jako przejaw radykalnego egalitaryzmu, daleko wychodzącego poza sferę równości formalnej. Przestrzega, iż

pogarda dla heroizmu to tylko jedna z wersji błędnie pojmowanej zasady demokratyzmu, która odmawia ludziom wielkości i postuluje, aby każdy czuł się dobrze we własnej skórze, nie musząc cierpieć niepochlebnych dla siebie porównañ ${ }^{66}$.

Takie podejście uniemożliwia jednak moralne kształtowanie młodego człowieka, a de facto skutkuje bezkrytycznym przyzwoleniem i bezmyślną akceptacją wszelkich jego wyborów. Przypomina, że przecież

bycie moralnym wiąże się z przezwyciężaniem samego siebie, czego nie wymaga bycie mądrym i pięknym czy uzewnętrznianie innych przymiotów uchodzących za godne pozazdroszczenia. $Z$ tego też powodu moralne postępowanie budzi tak wielki szacunek i dlatego tak wielka jest pokusa, by je naśladowaćc7.

Zinstytucjonalizowana neutralność będąca pokłosiem radykalnie pojmowanego egalitaryzmu skutkuje również takim planowaniem programów nauczania przedmiotów akademickich, aby „wymusić na studentach konstatację, że istnieją inne światopoglądy, a światopogląd zachodni nie jest od nich lepszy" ${ }^{68}$. Rand i Bloom nie mają wątpliwości, że wychowanie w takim duchu sprawia, że młodzi ludzie przestają odczuwać szczególny związek ze swoim dorobkiem kulturowym, a jednocześnie coraz gorzej radzą sobie ze zrozumieniem procesów historycznych i rozwoju cywilizacyjnego. Przyjęta strategia wydaje się całkiem logiczna i skuteczna, bo przecież - wedle postulatów radykalnych ruchów lewicowych - „młodzieży należy wpoić uszanowanie innych sposobów życia. Najłatwiej to osiągnąć, jeżeli uczniom obojętna jest prawdziwa treść tych sposobów życia" ${ }^{\prime 6}$. Sprzyja także wzbudzanie obojętności względem własnego dorobku kulturowego. Nowy uniwersytet coraz

\footnotetext{
${ }^{66}$ Tamże, s. 81.

${ }^{67}$ Tamże.

${ }_{68}$ Tamże, s. 43.
}

${ }^{69}$ A. Bloom, Umyst zamknięty, s. 41. Autor ten dowodzi jednak, że taka strategia jest ze wszech miar błędna, a może nawet naiwna. Dowodzi, że „równa dla wszystkich ochrona prawna nie chroni człowieka od pogardy i nienawiści jako Żyda, Włocha czy Murzyna". Tamże, s. 35. Podkreśla, że prawdziwe wychowanie w duchu szacunku i tolerancji nie może być nigdy realizowane poza wychowaniem moralnym, którego elementem zawsze musi być kształtowanie umiejętności podejmowania moralnych decyzji i oceniania postaw. 
bardziej oddala się tym sposobem od swojego tradycyjnego wzorca, bo przecież - jak podkreśla Bloom - wyłaniająca się między dyskutantami „różnica poglądów powinna rodzić pytanie, który pogląd jest prawdziwy, a nie rezygnację z pojęcia prawdy"70.

\section{Defekt 6: Pogarda dla filozofii zamiast humanistycznego wykształcenia}

Paradoksalnie największe symptomy kryzysu uniwersytetu Bloom dostrzega na wydziałach humanistycznych, które w ostatnich latach zostały zdominowane przez historycyzm i relatywizm, a powszechnym zjawiskiem stał się deficyt dla poszanowania wszelkich tradycji oraz dominacja kultu użyteczności ${ }^{71}$. Wyrugowano właściwie $\mathrm{z}$ większości humanistycznych kierunków filozoficzny namysł nad największymi egzystencjalnymi pytaniami, jakie w całej historii naszej cywilizacji stawiał sobie człowiek. Rand wykazuje, że zwolennicy użytecznościowego czy pragmatycznego traktowania edukacji uniwersyteckiej

nie zauważają, że tylko jedna dziedzina myśli pozwala ludziom radzić sobie z problemami o tak wielkiej skali, że tylko ona ma zdolności integrowania i jednoczenia ludzkiego działania; nie zważają, że tą dziedziną jest filozofia, której oni właśnie powierzyli zadanie dezintegracji i niszczenia ich pracy ${ }^{72}$.

Wiele wydziałów filozoficznych - nie tylko w Stanach Zjednoczonych ograniczyło refleksję filozoficzną do obszaru tak zwanej filozofii analitycznej oraz badań semiotycznych. Autorka Powrotu człowieka pierwotnego zauważa, że „zwolennicy analizy lingwistycznej stwierdzają, że zadaniem filozofii nie jest rozpoznawanie uniwersalnych zasad, ale wyjaśnianie ludziom, co mają na myśli, gdy używają języka"73. To niespotykane jak dotychczas samoograniczenie pola badań i dociekań filozoficznych. Właśnie jako reakcję na temu podobne zjawiska - dostrzegalne zresztą jeszcze przed rebelią lat 60. - Rand podjęła się twórczości prozatorskiej, a w swoich powieściach i opowiadaniach zachęcała przede wszystkim młodych ludzi do podejmowania namysłu filozoficznego, oferując im jednocześnie alternatywną formę filozoficznej edukacji ${ }^{74}$.

Współczesne uniwersytety ponoszą ponadto jeszcze jedną porażkę: nie wdrażają młodych ludzi w kulturę książki. Szczególną rangę zaniechanie to uzyskuje - z oczywistych względów - w praktykach wydziałów humanistycznych. Bloom stwierdza dobitnie, że

${ }^{70}$ Tamże, s. 48.

${ }^{71}$ I. Chłodna-Błach, The Crisis of American Education, s. 261.

72 A. Rand, Powrót człowieka pierwotnego, s. 37.

${ }^{73}$ Tamże, s. 29.

${ }^{74}$ R.L. Powell II, Ayn Rand's Heroes: Between and Beyond Good and Evil, Electronic Thesis, Treatises and Dissertations, Florida State University Libraries 2006, s. 22. 
młodzi Amerykanie po prostu nie lubią już czytać, a zatem nie czytają. Nie ma już kanonicznych książek, które by ich kształtowały, przez pryzmat których postrzegaliby rzeczywistość, które kształtowałyby ich światopogląd $\mathrm{d}^{75}$.

Lektury stanowiły dotychczas niezwykle istotny czynnik uczestnictwa w kulturze, a zarazem przyswajania kultury. Zdaniem Blooma, „zaniechanie lektury dobrych książek zarazem osłabia zmysł widzenia i umacnia najzgubniejszą z naszych skłonności - przekonanie, że nie istnieje nic prócz «tu i tera$\mathrm{z} »^{\prime \prime 76}$. Rand wskazuje ponadto, że mamy de facto do czynienia z systematycznym zanikiem umiejętności czytania wśród współczesnych dzieci, młodzieży i studentów ${ }^{77}$. Zjawisko to stanowi konsekwencję systematycznego rugowania z systemu kształcenia powszechnego elementów edukacji humanistycznej. Bloom i Rand nie zgadzają się z tezą, jakoby do prawdziwego i pełnego zrozumienia naszej kultury wystarczyły najnowsze twory kultury popularnej, na przykład filmy. Krytycy Blooma podnoszą, że tak samo jak większość filmów nie zasługuje, by być oglądanymi, tak też większość książek nie zasługuje, by je czytać ${ }^{8}$. Kiedy jednak Rand i Bloom mówią o czytaniu, wówczas na myśli mają raczej obcowanie z literaturą, która weszła do kanonu klasyki kultury europejskiej i amerykańskiej. Bloom wyjaśnia, że

choć byłoby głupotą sądzić, że wiedza książkowa wystarczy za całą edukację, jest ona zawsze konieczna, zwłaszcza w czasach, kiedy samo życie dostarcza niewielu godnych naśladowania wzorców człowieczeństwa ${ }^{79}$.

Lektura książek pozwala również ukształtować w uczniu czy studencie szereg umiejętności, jak chociażby odróżnianie zagadnień ważnych od nieważnych czy problemów centralnych od marginalnych ${ }^{80}$.

\section{Zakończenie \\ Stan uniwersytetów jako przejaw przemian kulturowych}

Rand i Bloom niezwykle krytycznie oceniają stan współczesnych uniwersytetów amerykańskich. Niezależnie od tego, że ich oceny mają charakter stosunkowo zachowawczy, wypływają niewątpliwie z konserwatywnego światopoglądu i głębokiego przywiązania do klasycznej filozofii i humanistycznych tradycji akademii, to jednak warto w głosy te się wsłuchać, chociaż-

\footnotetext{
${ }^{75}$ A. Bloom, Upadek Uniwersytetu, s. 241.

76 A. Bloom, Umyst zamknięty, s. 78.

77 A. Rand, Powrót człowieka pierwotnego, s. 97.

${ }_{78}$ S. Cavell, Who Disappoints Whom? Critical Inquiry, 1989, 15, s. 609-610.

79 A. Bloom, Umyst zamknięty, s. 24.

80 A. Bloom, The Crisis of American Democracy, s. 120.
} 
by dlatego, że we współczesnych Stanach Zjednoczonych coraz częściej do prezentowanej przez nich argumentacji się wraca. Blooma krytyka uniwersytetu jest tożsama z jego krytyką stanu Ameryki ${ }^{81}$. Tak samo zresztą widzi to Rand, według której „kraj w całości stanowi odzwierciedlenie stanu uniwersytetów" 82. Tym samym, jeśli uniwersytety jako twierdze „rozumu, wiedzy, uczoności cywilizacji" skapitulują, to skapituluje również cały kraj ${ }^{83}$. Można więc potraktować krytykę współczesnego uniwersytetu według Rand i Blooma jako asumpt do refleksji - nawet bardzo pesymistycznej i wręcz oskarżycielskiej - nad stanem współczesnej kultury i kondycją współczesnego człowieka. Z dużym prawdopodobieństwem defekty współczesnego uniwersytetu, które zostały powyżej scharakteryzowane, można by również przenieść na negatywne aspekty funkcjonowania współczesnych społeczeństw demokratycznych, a tym samym - negatywne zjawiska kulturowe. Bloom stwierdza jednoznacznie, że stan amerykańskich uniwersytetów dowodzi jedynie, że „relatywizm kulturowy przezwyciężył imperializm intelektualny Zachodu, czyli jego roszczenia do uniwersalizmu" ${ }^{84}$. Można by domyślać się z tego stwierdzenia, że "wojna o uniwersytety" została już przegrana. Jednakże ani Bloom, ani Rand nie są w swoim pesymizmie aż tak radykalni.

Nie wiedzą, niestety, w jaki sposób zmienić postawy studentów, którzy przy wyborze uczelni i kierunku studiów kierują się pragmatyzmem promowanym przez współczesne społeczeństwa konsumpcyjne, funkcjonujące w warunkach gospodarki wolnorynkowej. Studenci ci w wyborach przedmiotu studiów jako zasadniczy cel stawiają swoją przyszłą karierę zawodową; nie kieruje nimi pragnienie „wzrostu duchowego". Natomiast, uniwersytety umożliwiają tymże studentom odbycie studiów ograniczonych jedynie do przyswojenia sobie technicznej strony funkcjonowania wybranego sektora życia, gdyż w zdemokratyzowanym uniwersytecie oferuje się studentom dziesiątki dyscyplin, które uzyskały równorzędny status, choć niekoniecznie wszystkie taki mieć powinny ${ }^{85}$. Do zmiany status quo - bo jednak zarówno Rand, jak i Bloom dostrzegają jeszcze jakąśs szansę - potrzeba ukształtowania się ruchu, który podejmie się długiego marszu ku odtworzeniu tego, co zostało utracone. Rand jest pewna, że

pod nieobecność intelektualnej opozycji idee rebeliantów będą stopniowo podlegać kulturalnej absorpcji. Nie kwestionowane absurdy dnia dzisiejszego jutro staną się akceptowanymi sloganami ${ }^{86}$.

\footnotetext{
${ }^{81}$ C.G. Ryn, Allan Bloom and Straussian Alienation, Humanitas, 2012, XXV, 1-2, s. 18.

82 A. Rand, Powrót człowieka pierwotnego, s. 40.

83 Tamże, s. 44.

${ }^{84}$ A. Bloom, Umyst zamknięty, s. 47.

${ }^{85}$ I. Chłodna-Błach, The Crisis of American Education, s. 262.

${ }^{86}$ A. Rand, Powrót człowieka pierwotnego, s. 56.
} 
Wskazuje jednocześnie, że „znajdujemy się dzisiaj na intelektualnej ziemi niczyjej, a o przyszłości przesądzą ci, którzy odważą się ruszyć z okopów status quo" ${ }^{\prime 27}$. Bloom twierdzi, że „dzisiejsze uniwersytety jako instytucje wyrządzają ogromną krzywdę naturze ludzkiej"88. Aby proces ów zatrzymać, konieczne jest ukształtowanie się świadomej tych negatywnych zmian opozycji, która będzie gotowa do długiej walki z obrońcami „multiwersytetu”.

\section{BIBLIOGRAFIA}

Bloom A., The Republic of Plato, Basic Books, New York 1968.

Bloom A., The Crisis of American Democracy and Liberal Education. Collected Essays, Internet Archive 1986.

Bloom A., Szekspir i polityka, Wydawnictwo Arcana, Kraków 1995.

Bloom A., Romeo i Julia, Kronos, 2011, 3.

Bloom A., Umyst zamknięty, przekł. T. Bieroń, Wydawnictwo Zysk i S-ka, Poznań 2012.

Bloom A., Upadek Uniwersytetu, przekł. A. Serafin, Kronos, 2016, 4.

Branden N., Zdrowie umystowe versus mistycyzm i samopoświęcenie, [w:] A. Rand, Cnota egoizmu. Nowa koncepcja egoizmu, przekł. J. Łoziński i in., Zysk i S-ka Wydawnictwo, Poznań 2000.

Cavell S., Who Disappoints Whom? Critical Inquiry, 1989, 15.

Chłodna-Błach I., The Crisis of American Education and Reforms Proposals according to Allan Bloom, Studia Gilsoniana, 2004, 3.

Czarnecki M.J., Co znaczy Uniwersytet? Dialogi Polityczne, 2007, 7.

Polakowski M., O zmierzchu pewnej idei, Dialogi Polityczne, 2007, 7.

Powell II R.L., Ayn Rand's Heroes: Between and Beyond Good and Evil, Electronic Thesis, Treatises and Dissertations, Florida State University Libraries 2006.

Rand A., Cnota egoizmu. Nowa koncepcja egoizmu, przekł. J. Łoziński i in., Zysk i S-ka Wydawnictwo, Poznań 2000.

Rand A., Hymn, przekł. S. Bijak, Zysk i S-ka Wydawnictwo, Poznań 2001.

Rand A., Powrót człowieka pierwotnego. Rewolucja antyprzemysłowa, przekł. Z.M. Czarnecki, Zysk i S-ka Wydawnictwo, Poznań 2003.

Rand A., Źródło, przekł. I. Michałowska, Zysk i S-ka Wydawnictwo, Poznań 2007.

Rand A., Atlas zbuntowany, przekł. I. Michałowska, Zysk i S-ka Wydawnictwo, Poznań 2008.

Ryn C.G., Allan Bloom and Straussian Alienation, Humanitas, 2012, XXV, 1-2.

87 Tamże, s. 58.

88 A. Bloom, Upadek Uniwersytetu, s. 249. 